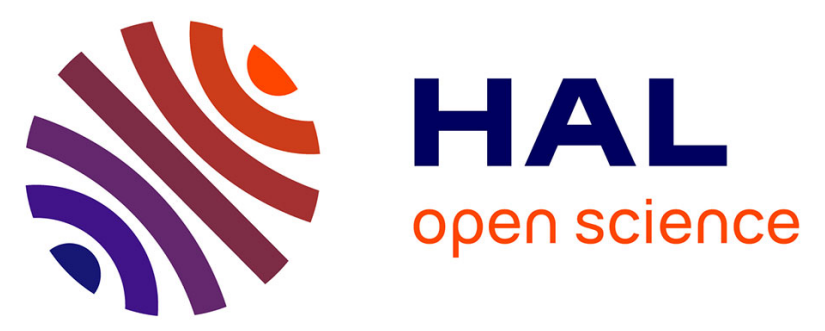

\title{
Sustainable groundwater management in France and Australia: setting extraction limits, allocating rights and reallocation
}

Cameron Holley, Jean-Daniel Rinaudo, Steve Barnett, Marielle Montginoul

\section{- To cite this version:}

Cameron Holley, Jean-Daniel Rinaudo, Steve Barnett, Marielle Montginoul. Sustainable groundwater management in France and Australia: setting extraction limits, allocating rights and reallocation. Sustainable groundwater management: a comparative analysis of French and Australian policies and implications to other countries, pp.1-15, 2020, 10.1007/978-3-030-32766-8_1 . hal-02531774

\section{HAL Id: hal-02531774 \\ https://hal.science/hal-02531774}

Submitted on 3 Apr 2020

HAL is a multi-disciplinary open access archive for the deposit and dissemination of scientific research documents, whether they are published or not. The documents may come from teaching and research institutions in France or abroad, or from public or private research centers.
L'archive ouverte pluridisciplinaire HAL, est destinée au dépôt et à la diffusion de documents scientifiques de niveau recherche, publiés ou non, émanant des établissements d'enseignement et de recherche français ou étrangers, des laboratoires publics ou privés. 


\title{
Chapter 1. Sustainable groundwater management in France and Australia: setting extraction limits, allocating rights and reallocation
}

\author{
Cameron Holley ${ }^{1}$, Jean-Daniel Rinaudo ${ }^{2}$, Steve Barnett $^{3}$ \\ and Marielle Montginoul ${ }^{4}$
}

1. University of New South Wales, Sydney, Australia

2. BRGM (French Geological Survey), Montpellier University, Montpellier, France

3. Department for Environment, Water and Natural Resources, Adelaide, South Australia, Australia

4. IRSTEA, G-EAU research unit, Montpellier, France

Corresponding author : c.holley@unsw.edu.au

\begin{abstract}
This chapter briefly introduces the main policy developments from both France and Australia regarding groundwater management and their particular approach to setting caps, allocating rights and allowing reallocations. It then presents the objectives of the book and explores the book's contributions under four key themes, namely groundwater and policy approaches in France and Australia, capping water use and defining sustainable abstraction limits, reducing entitlements to sustainable limits, and comparisons between France, Australia and other international groundwater developments.
\end{abstract}

\section{Introduction}

During the last three decades, economic development of both urban and rural areas has increasingly relied on groundwater water resources, which supply water for around $40 \%$ of irrigated lands, half of all drinking water, and increasingly plays a central role in unconventional energy developments, such as unconventional gas. However, this development has often taken place in a context of "weak" governance (Faysse et al, 2014), in which groundwater was often considered as an open access 
resource. In many regions around the world, individual water users acting independently according to their own self-interest, without considering the aggregate impact of their decisions of the sustainability of the resources, have depleted groundwater, illustrating the "tragedy of the commons" described by Hardin (1968). Due to excessive pumping by, groundwater levels have been declining, affecting dependent ecosystems, in particular by reducing river base-flows, disconnecting rivers from aquifers and lowering water levels in wetlands. Overdraft has led to land subsidence and increased cost of pumping, as well as irreversible deterioration of many aquifers through intrusion of saline or contaminated water from adjacent aquifers (Fienen and Arshad, 2016; van der Gun 2012, FAO 2016a). This trend has been documented in many (semi)-arid, but also temperate regions in Asia (China, India, Pakistan), America (Chile, USA, Mexico), Europe (Spain), North-Africa and the Middle East (Morocco, Jordan) and to some extent, in both Australia and France.

While contributing to creating wealth and alleviating poverty in the short term, these problems arising from groundwater development could lead to the collapse of thriving agricultural economies which are too strongly dependent on groundwater (Petit et al., 2018). These threats are a matter of increasing concern to many nation States that have supported agricultural development through subsidies and infrastructure development. Indeed, as many States and the global community now recognise (see e.g. Sustainable Developmnt Goal 6), on-going groundwater overdraft could render these investments worthless and transform areas of former economic expansion into regions of poverty.

A critical issue for policy makers is ensuring that groundwater extraction is sustainable in the long term. Although there are large groundwater policy and governance gaps across the globe, where policies do not exist, attention is paid to models and success stories that could be replicated (FAO 2016a; Molle and Closas, 2017). Many studies have been carried out into groundwater problems, and many technical solutions have been proposed (e.g. recharge, water transfers, conjunctive use, water saving technologies) and institutional frameworks (e.g. collective and common pool resource approaches) (Jakeman et al 2016; Ostrom 1990; van der Gun 2012; Giordano 2009, Villholth et al, 2017). Yet despite these many institutional and technical tools that have been designed and developed over the years, their actual implementation has remained a significant global challenge. As the FAO (2016b) has noted: "one thing is clear; it is not the formulation of laws and regulations that will make a difference, but their implementation and adoption ...".

This edited collection accordingly provides insights and understanding by bringing together practitioners and academics to reflect on their experience with developing and implementing groundwater management policy. In this regard, the book focuses on a policy model and its implementation that a number of academics and international agencies have been promoting. This policy model consists of (i) capping total resource use, (ii) allocating use rights accordingly and (iii) defining rules to allow reallocation and adaptation to changing economic and climatic conditions. Capping consists of calculating and imposing a Sustainable Abstraction Limit 
(SAL), which when observed, guarantees the continuity of use for future generations and ensures the proper ecological functioning of groundwater dependent ecosystems such as streams and wetlands. The available resource defined by the SAL is then allocated to users via rights, which can either be individual or collective, defined in volume or pumping rate and taking the form of administrative permits, concessions or full property rights. Those rights can be reallocated over time, based on either administrative procedures (waiting list), market mechanisms (if rights are made tradable), or negotiated rules defined by users themselves (decentralized selfregulated management). This allows adaption of the initial allocation of rights in response to changing economic or demographic conditions, or to the exit or entry of users, with the primary objective of seeking maximum economic returns from use of the resource. Finally, rules are set-up to adjust water entitlements in the event of a reduction in the available resource.

This generic model underpins groundwater management policies implemented in a number of high or intermediate income countries such as Australia, Chile, Western United States, Spain, Mexico, and France. While this model is one that other countries, including less developed ones, could aspire to, it is important to highlight that it is not a rigid prescriptive model and that it can be adapted to very diverse technical, social and political contexts and can accommodate different concepts of social justice, water rights, decentralisation and trade-offs between environment, economics and equity. It is equally important to note the difficulties likely to emerge during the implementation phase, whose duration is often measured in years, if not decades. This book highlights this diversity of implementation approaches, problems and successes, though a comparative analysis of several case studies in France and Australia, two countries which have a long history in groundwater management reforms and implementation.

In the early 1990's, both countries initiated a groundwater management policy reform which broadly followed the model presented above. As displayed in Figures 1. 1 and 1. 2, both nations initially followed a broadly similar trajectory, that began with access regimes based around individual rights, before shifting in the $20^{\text {th }}$ Century to the regulation and licensing of wells/bores, but with little consideration of sustainable extraction limits. It was during the late 1990's and early 2000s that both nations commenced major reforms based around the policy model of capping total resource use, allocating use rights and defining rules to allow reallocation and adaptation. Notwithstanding this commonality, as shown in Figures 1.1 and 1.2 and throughout the book, both nations diverge in how this model was given effect in practice.

In the following discussion, we briefly introduce the main policy developments from both France and Australia regarding groundwater management and their particular approach to caps, rights and reallocations. 


\section{Groundwater management policies in France and Australia}

\subsection{Overview of the French approach}

In France, the historical evolution of groundwater development and management can be broken down into four major phases (see Figure 1. 1). The initial phase corresponds to a system of free access to the resource, in which landowners can freely appropriate the water located beneath their land. The proliferation of deep industrial boreholes and the rapid development of confined aquifers that occured during the 1850 's and early 1900 's led to some occurrences of overexploitation. This threatened the resources regarded as being of strategic importance for supplying drinking water, which prompted the State to intervene.

The first groundwater legislation was subsequently passed in 1935. It involved setting up a permit system for wells and boreholes, which essentially aimed to control industrial use in order to protect the supply of drinking water. Between the end of the 1960s and the early 1990s, the increase in the number of agricultural boreholes, often tapping shallow aquifers, generated new cases of overexploitation and conflict over environmental protection issues. The 1992 Water Act provided a response to this crisis by strengthening the State provisions for controlling abstraction. In particular, it established the necessary conditions for volumetric management of water abstraction, including the obligation to record actual use (metering) and the allocation of individual abstraction quotas. Although the mechanisms were in place, overexploitation problems persisted due to over-allocation.

The third phase was initiated by European legislation, known as the Water Framework Directive. This Directive obliged member states to restore all their bodies of water to a satisfactory state in terms of quality and quantity. The French implementation strategy of that Directive was laid down in the 2006 Water Act which requires capping total abstraction and sharing the available resource among users. As the cap was lower than historical use in many groundwater and river basins, managers had to design rules to reduce entitlements. To do so, the 2006 Act encouraged the development of a collective approach to water allocation, notably through the creation of the Water Users' Associations (called OUGC). In the first step, this collective management was only implemented to manage agricultural users, which represent the highest number of users and frequently the highest share of resource use.

The final phase will involve developing new and flexible water management mechanisms capable of adapting to a rapidly changing economic and climatic environment. 


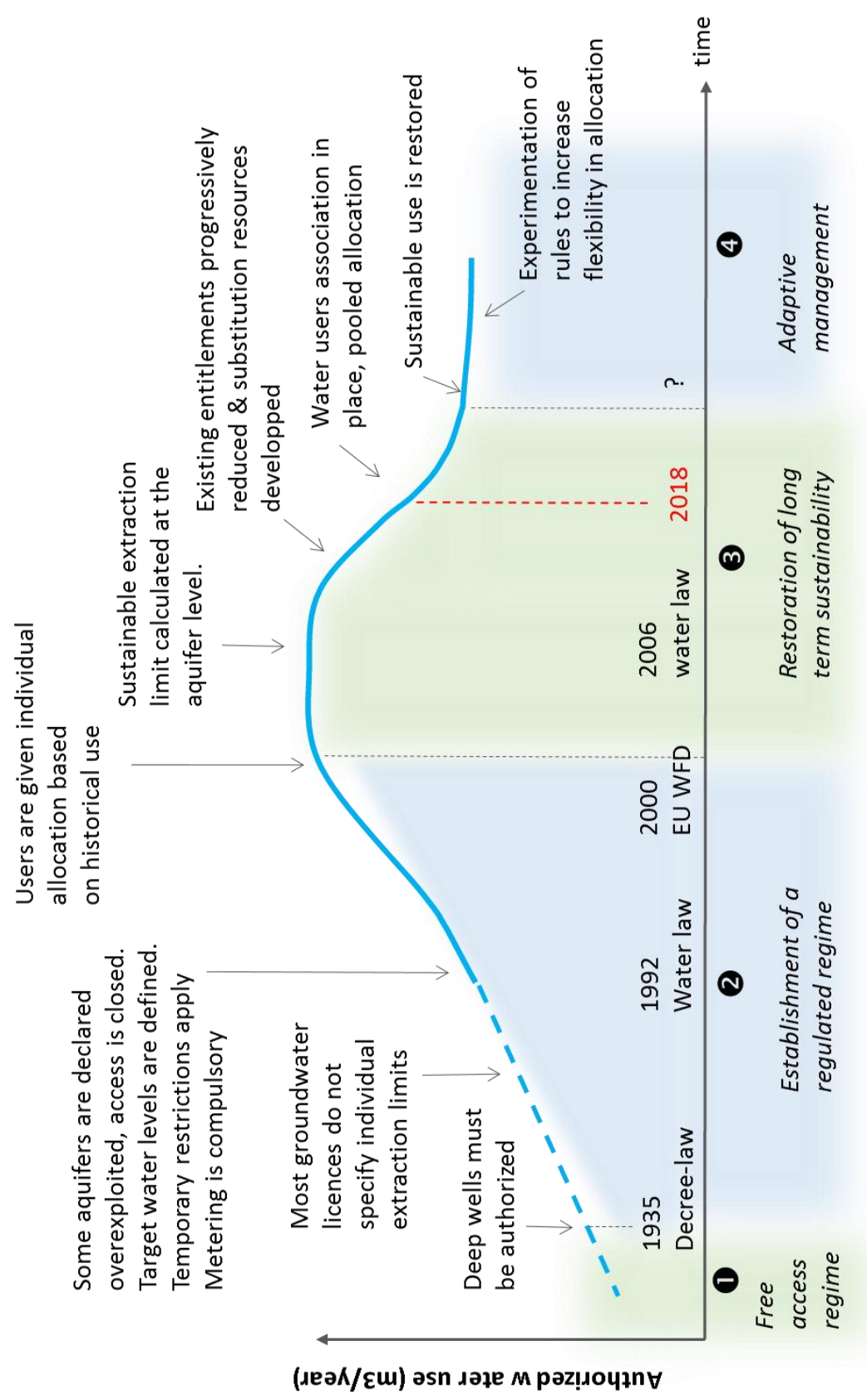


Figure 1. 1: The four policy phases for regulating groundwater abstraction in France

\section{Overview of the Australian approach}

Following thousands of years of Indigenous rules and concepts realting to water and the environment (Marshall 2017) the transplantation of the Anglo common law riparian and capture rights granted landholders the ability to conditionally access and use water adjacent to and beneath their land. As demand for water by growing urban centres increased, the inadequacies of this approach became apparent. This prompted the first state legislation in 1886 which vested the right to the use, flow and the control of water in the state, marking the transition from rights to state legislative regimes (Gardner et al. 2017). Reflecting broadly similar developments in France, Australia's states progressively vested control over water in the Crown and abolished or displaced existing common law rights in response to increasing groundwater development in the 1960s and 1970s, creating a system of licencing (albeit one that did not pursue wide ranging caps on water use) (Holley \& Sinclair 2018).

Echoing comparable developments in France, Australia's modern water reform journey commenced in the early 1990s motivated by concerns about the efficiency and equity of water allocations and also with environmental sustainability. Under the Australian constitution, the States historical had primary responsibility for water management, but the initial reforms were founded on ideas of intergovernmental agreements and action through the Council of Australian Governments ('CoAG'). A national water framework was agreed to in 1994 (CoAG 1994), closely followed by a similar 1996 Framework for Improved Groundwater Management.

These reforms created the emblematic aspect of Australia's approach which is the creation of property rights to extract water, within extraction limits set using scientific methods. Rules for the trading of entitlements would support the intention that water would be used in the most efficient and productive way. The reforms also encouraged a system of regulatory enforcement. Perhaps the main contrast to the French approach is that the Australia policy model sets out aspirations for marketbased reforms.

A subsequent 2004 Intergovernmental Agreement known as the National Water Initiative (NWI), consolidated the 1994 reforms and aimed to embed a nationallycompatible water market, progressively remove barriers to water-trading, facilitate efficient water use and address adjustment issues (Cwth of Aus. 2004). This next wave of reforms also aspired to return over-allocated or overused systems to environmentally-sustainable levels of extraction by encouraging the development and finalisation of aquifer and catchment based statutory water allocation plans, and making statutory provision for environmental and other public benefit outcomes. Community engagement, partnerships and consultation throughout plan development and review was deemed essential to this adjustment process. 


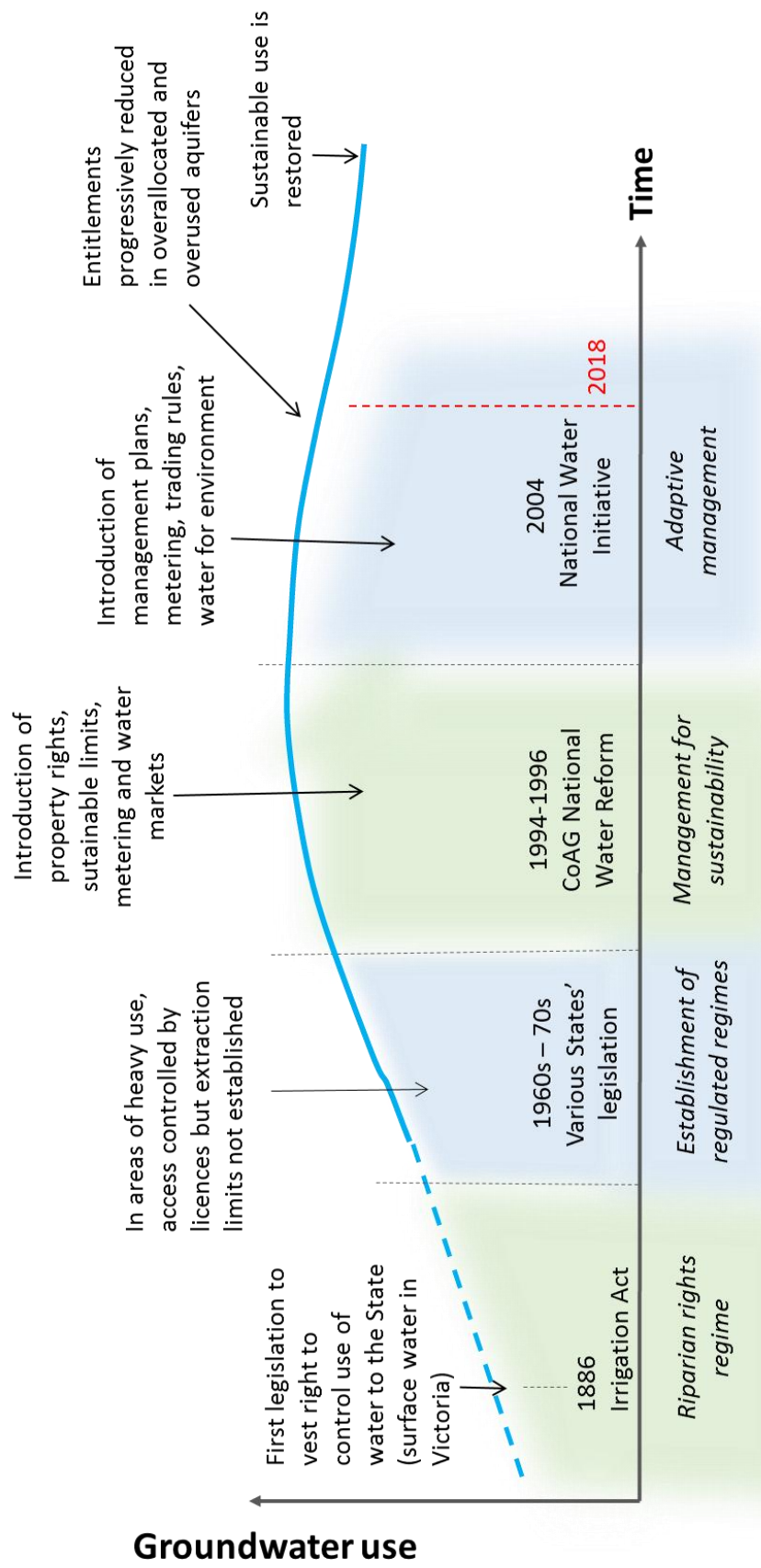


Figure 1. 2: : The four policy phases for regulating groundwater abstraction in Australia

\section{Objectives and scope of the book}

The main objective of this book is to describe and analyse a variety of possible approaches and policy pathways to implement sustainable groundwater management, based on a comparative analysis of selected case studies in France and Australia. The book strictly focuses on quantitative management and does not cover in detail water quality or pollution management issues.

One of the specific features of the book is that a majority of the contributors are water professionals who have been involved for several decades in groundwater policy making, planning and implementation of management plans. Most of the contributors to this book participated in a French - Australian workshop organised in Montpellier (France) in October 2016 where they presented and discussed case studies that are covered in more detail in the following chapters and represent a significant contribution to the empirical water management literature that has not been published elsewhere, even in grey literature.

Recognising that groundwater has become an interdisciplinary subject (van der Gun 2012, p i) the originality of the contributions also lies in the different disciplinary perspectives covered in many chapters (hydrogeology, economics, planning and social sciences in particular).

In addition to the case studies, the book also presents the results of a comparative analysis conducted by these French and Australian water professionals, supported by a group of academics. This dialogue, initiated during the Montpellier workshop, led to the identification of similarities but also fundamental differences which are analysed and presented as alternative policy options in the conclusion of the book these differences being mainly related to the role of the State, the community and market mechanisms in groundwater management. Given the importance of linking the experiences of Australia and France to other global developments, we also invited leading water academics to reflect on groundwater management experiences in other countries, in particular in Chile and the US (particularly California).

\section{Structure of the book}

The book is divided into four main sections containing a total of 27 chapters. Below is a brief overview of the sections and chapters. 


\subsection{Section 1: Groundwater and Policy Approaches in France and Australia}

The first section provides background information on the French and Australian groundwater policy context at Federal/national levels as well as at river basin and catchment levels, where long term planning and implementation of groundwater policy actually takes place. The contributors provide a general assessment of the situation of groundwater depletion in both countries, with a focus of drought years, including the Millennium Drought in Australia and its impact on groundwater resource in the Murray Darling Basin. Groundwater professionals in this first section also describe how groundwater policies have progressively developed over the last 25 years, using primary information accumulated from their long experience, with the support of academic authors providing conceptual models for policy analysis.

Chapters 2-5 commence the section by outling groundwater and management contexts in France. Maréchal and Rouillard (Chapter 2) describe the status of groundwater resources in France. The chapter highlights the geology and types of aquifers, as well as use of groundwater resources across domestic use, industry and agriculture. It notes that although France has not yet faced extreme cases of aquifer depletion, the long-term management challenges relate to the decrease of recharge due to climate change, sea level rise along the coast, and future change in groundwater use. It concludes by suggesting three core adaptation strategies.

In Chapter 3, Rinaudo examines the development of groundwater policy in France. The chapter maps a shift from private property to increasing State regulation of its use, broadly akin to similar developments in Australia discussed in Chapter 7. The chapter characterizes the development of the 2006 water law as constituting a clear break in French water policy, and examines the changes it introduced and the subsequent shift from a private to a common property regime.

The groundwater planning process in France resulting from the 2006 water law, is analysed in Chapter 4. Rinaudo et al explore the framework of local plans (SAGE) and strategic master plans for managing river basins (SDAGE). This chapter describes how strategic blueprints are formulated and implemented, including a historical analysis of 20 years of groundwater planning in the Adour-Garonne and Loire-Bretagne river basin districts.

Transitioning from the basin to the local aquifer level, Chapter 5 highlights lessons from twenty years of local volumetric groundwater management in the Beauce aquifer. In this chapter, Verley draws on personal experience to describes the evolution of management mechanisms for water abstraction, the characteristics of the water resource, its various uses, the problem of overexploitation and how the management plan evolved. The chapter also reflects on prospects for change.

Chapters 6-9 shift the focus from the northern to the southern hemisphere, with Barnett et al. introducing groundwater in Australia (chapter 6). The chapter charts the social, economic and environmental features of groundwater resources, while discussing the various types of aquifers, their development and future management 
issues, including impacts of climate change, impacts of mining and declining government funding.

Building on the overview of Australia's groundwater resources, Nelson et al (Chapter 7) chart the development of groundwater management in Australia, and how the experiences of other countries were taken into account. Recognising that the states and territories continue to be the primary managers of groundwater and are responsible for licensing processes and adopting legally enforceable plans to manage extraction, the chapter provides some case studies of differing approaches to groundwater management from different Australian states.

In Chapter 8, Walker et al turn their attention to perhaps the most well known water management context in Australia, the Murray Darling Basin. The chapter describes the nature of groundwater systems in the Basin, noting that management of groundwater on a basin-scale had a lower priority compared to the more controversial surface water resources. It explains how a coordinated joint management plan for the increasingly important groundwater resources in the Basin was developed using a methodology to determine sustainable extraction limits across five states and territories. The chapter concludes its analysis by considering some of the challenges arising from this joint management approach.

Concluding Section 1, Chapters 9 and 10 focus on the dissemination and communication of groundwater information in both France and Australia. Sharples et al (Chapter 9) uses examples from Australia and France to discuss similarities and differences in the two nations approaches to groundwater information systems, their history, and how these systems have been used to inform and improve groundwater management. A range of examples are explored including local management, national data standardization, online data sharing, and environmental impact assessment before summing up the future directions in this field.

Finally, in chapter 10, Richard-Ferroudji and Lassaube draw on 11 case studies from France to report on a number of communication approaches and activities and how they were used to make groundwater "visible" for various stakeholders, including the general public, farmers and elected representatives. The chapter introduces a framework to analyse communication approaches and tools before assessing the use of the tools, and their benefits and limits, concluding by offering recommendations.

\subsection{Section 2: Capping Water Use and Defining Sustainable Ab- straction Limits}

Building on the overview provided in Section 1, the second section examines the first part of the policy model, specifically looking at how water managers cap total water use by defining sustainable abstraction limits. Chapters in this section investigate how this process is conceptually defined in the two countries, revealing the diversity of trade-offs made between environment and economic activities. The section also provides a good overview of the tools and groundwater models used to 
estimate extraction limits at different geographic and time scales, considering climate variability and uncertainties about future changes.

This section commences with a review of conceptual approaches, methods and models used to assess abstraction limits for unconfined aquifers in France (chapter 11). Based on the analysis of over 30 studies, Arnaud shows that the estimation of this limit, called Maximum Permissible Volume (MPV) in France, is complicated by numerous uncertainties, data availability constraints and simplifying assumptions made by hydrogéologists. These technical limitations of hydrogeological studies allow users contesting MPV, which are often renegotiated.

Chapter 12 then focuses on the challenges of setting abtraction limits in confined aquifer, based on experiences from the deep confined aquifers in the Bordeaux region in France. In this chapter, lapyuade et al. explore the historical development of cap setting, noting that risks of overexploitation of these resources was a driver for the implementation of specific regulations. Implementation of management policies and investigations to improve knowledge and develop groundwater flow models are also examined, and as the chapter explains, the local stakeholders involved in aquifer management employed these modelling tools to create the principles and policies for controlling groundwater-abstraction.

Chapter 13 (Lecointe et al.) continues the focus on France with an analysis of the process and tools for determining sustainable annual allocations in the Tarn-et-Garonne alluvial aquifer. Using the previous history of events, the authors demonstrate the complexity and lengthy period of time required to develop a groundwater flow model that can be used by a government agency to support water allocation decisions. This chapter depicts a unique French water management approach where groundwater allocations for water users are updated every year, based on observed resource conditions. The chapter concludes with some unique insights on a shift in responsibility for the allocation process from the state to collective water user associations.

The evolution of the concept of 'sustainable development' for groundwater resources in Australia is discussed in Chapter 14 by Pierce and Cook. Originally, the 'safe yield' approach was employed whereby the upper limit for extraction was determined by the estimation of recharge. However, due to the difficulties and uncertainties in estimating recharge, and the fact that this approach does not allow for environmental uses of groundwater, management plans are increasingly moving toward the notion of acceptable impacts based on specified resource condition limits. They discusses in depth the methods used to evaluate four main areas of risk namely: storage capacity, groundwater dependent ecosystems, groundwater quality and aquifer integrity.

In Chapter 15, McGivern provides a useful case study of a Western Australian approach to establish sustainable pumping limits. The chapter draws on insights from the management of an aquifer in the Perth's North West Urban Growth Corridor, where declining winter rainfalls, and an increase in average temperatures has complicated access to sustainable water resources for a fast growing population. 
McGivern examines how the sustainable yield of the aquifer was determined, and argues that both groundwater flow models and simple spread sheet analytical models using representative hydraulic parameters can play important roles. The chapter also highlights how co-operation between water providers and regulators and flexibility in the management approach are important ingredients for successful outcomes.

The famous Barossa Valley wine region is the subject of Chapter 16 where Pierce and Cranswick describe a new responsive and participatory management approach using resource condition limits. Consultations were held with a representative community group to determine the level of risk of adverse impacts occurring as a result of groundwater extraction that groundwater users think is unacceptable. The impacts considered were changes measured by resource condition indicators such as water levels, groundwater discharge to streams and the ingress of higher salinity groundwater. A groundwater flow model was then used to determine what extraction rates would result in acceptable levels of risk.

\subsection{Section 3: Reducing Entitlements to the Sustainable Limit}

Despite efforts to allocate entitlements and set sustainable limits for extraction, a common challenge in many nations, including France and Australia, is overallocation where the volume of entitlements exceeds the sustainable limit. The third section of the book provides insights on how to reduce entitlements down to sustainable limits in over-allocated resources. A common issue to all these chapters is how water use rights are defined and allocated to users. The Australian chapters assess the results attained since management plans and water markets were introduced to reduce depletion and achieve sustainable abstractions limits. A comparison of the Australian and the French approaches reveals fundamental differences in the political and philosophical values in relation to property rights of water and to the role that users communities should play in reallocation.

In Chapter 17, Shulte and Cuadrado Quesada discuss Australia's policy pathways for reducing entitlements when groundwater resources are over-allocated. The chapter highlights definitional challenges that initially hampered progress within Australia's federated structure, before examining attempts to reduce over-allocation and over-use in Australia's numerous groundwater management plans. The chapter highlights the challenges that led to slower than expected progress in addressing over-allocation and over-use, as well as exploring the use of various mechanisms and tools, including phasing in allocation reductions and carry-over provisions, compulsory reductions of allocations with compensation, moratoriums, conjunctive forms of management through collective action, including donations of groundwater rights in return for surface-water rights, and water licence/entitlement purchases by governments in the water market.

Douez et al. (Chapter 18) turn their attention to approaches for developing alternative water resources as compensation for reduced groundwater entitlements. In 
the case of the groundwater dependent Poitou Marshes in France, Douez et al. describe the relevant groundwater management policy and its response to the growth of irrigated agricultural as in other basins in central and western France (see Chapters 5,13 ). The chapter examines the significant reduction in historical water entitlements and pinpoints the difficulties encountered in implementing this reduction in a context of extreme competition between economic uses (agriculture, urban uses, and tourism) and environmental objectives. The chapter also reports on the complexities in developing integrated water management plans for basins, providing insights on the requirements for success and exploring issues of coordination between the State, the local water management board and users' associations where groundwater, rivers, wetlands, and canals and highly interdependent.

In Chapter 19, Barnett and Williamson examine approaches for allocation reductions and groundwater salinity management in South Australia. The chapter presents a case study of an exercise to reduce irrigation entitlements in an overallocated groundwater management area, driven by a longer-term risk to effective management of the resource. The chapter identifies a range of conditions that contributed to success, including establishing a good relationship and trust with the irrigators and staged reductions so that irrigators had time to adjust their operations.

Schuster et al (Chapter 20) provides a second example from Australia of approaches to reducing groundwater entitlements. Drawing on the history of events and the personal experience of Ken Schuster in the process of groundwater reductions in the Lower Murrumbidgee Groundwater Management Area, the case study provides lessons on water planning and policy approaches for reducing groundwater entitlements and the ensuing litigation by unhappy irrigators. The chapter points out the need to take local knowledge and concerns into account during the planning process, as well as providing adjustment mechanisms (e.g. economic compensation via Australia's Achieving Sustainable Groundwater Entitlements program) to ensure the long term sustainable management of groundwater.

In Chapter 21, De Luca and Sinclair offer some significant insights on Australia's innovative approach to managing entitlements, namely water markets. The chapter explores the challenges of using water markets to achieve sustainable water use, including physical and policy constraints that may determine where such markets operate. It examines how legal rights and water markets are used to manage groundwater in Victoria and other states throughout Australia, the success or otherwise of this policy approach, and its capacity to adapt to future pressures on water availability as a consequence of climate change.

The two next chapters address the issues of compliance and enforcement, an important component in ensuring any reduction in allocation is achieved in practice, and not undermined by groundwater theft or other illegal practices. In Chapter 22, Holley et al. draw on an empirical survey, regulator experiences and agent based modelling, to explore Australia's significant reform journey of compliance and enforcement policy over recent decades. They offer an analytical framework for studying groundwater compliance and enforcement and apply this frame to examines 
the experiences of a government regulator and the compliance and enforcement experiences of water users. It concludes with a summary of challenges and policy implications for groundwater compliance and enforcement regimes.

A similar set of compliance challenges emerge in Montginoul et al's analysis of groundwater regulation, compliance and enforcement in France (Chapter 23). They characterize compliance and enforcement as the 'Achilles heel' of French groundwater policy. Drawing on a review of existing grey and scientific literature and a series of interviews conducted with enforcement officers in 16 French counties, the chapter examines the regulations governing groundwater abstraction, followed by a description of how the law enforcement agencies are organised and how they operate. Montginoul et al analyse the infractions observed by regulators and the factors that may explain compliance and non-compliance, before highlighting the issues that limit the effectiveness of groundwater policy enforcement.

Section 3 concludes with a discussion by Rouillard of the role of sectoral policies to restore groundwater balance (chapter 24). Based on an analysis of European and French agricultural policies, Rouillard shows that sustainable groundwater quantitative management does not only depend on implementing the right water policy instruments. It also relies on enabling sectoral policies that work in synergy with water policy objectives.

\subsection{Section 4: France, Australia and International Comparisons}

The last section of the book broadens the perspective by examining the groundwater management approaches in Chile and California. Based on two contrasting case studies, Donoso et al. (Chapter 25) describes the implementation of a relatively sophisticated groundwater management framework in Chile which relies on a unique combination of State intervention, market mechanism and collective management. The two case studies presented by the authors also highlight the existence of problems common with France and Australia, in particular the occurrence of over-allocation, the lack of State resources to enforce existing regulation and difficulties to obtain support from users to reduce abstraction when aquifers are overexploited. Their chapter also sheds light on the political dimension of groundwater management, unveiling how strategic behaviours may impact management decisions. In Chapter 26, Harter presents the ongoing groundwater policy reform in $\mathrm{Cal}-$ ifornia, which promotes the development of sustainable groundwater management plans at the local level, with the State having substantial oversight over the planning process. Harter shows that many issues currently under discussion in California are similar to those which are still being debated in France, Australia and Chile. In conclusion, Chapter 27 draws together the lessons from the above chapters to offer a 'big picture' and comparative assessment of the Australian and French approach to the problem of groundwater depletion, and discusses which methods have been successful and which have not. 


\section{References}

Australian National Audit Office (ANAO). 2011. Restoring the balance in the Murray-Darling Basin: Audit Report No.27 2010-11. Canberra: Commonwealth of Australia.

Council of Australian Governments (COAG). 1994. Council of Australian Governments' Communiqué, 25 February 1994, Hobart .

Council of Australian Governments (COAG) (1996). National Framework for Improved Groundwater Management. Aus. Gov.

Commonwealth of Australia (Cwth of Aus). 2004. Intergovernmental Agreement on a National Water Initiative. Canberra: Commonwealth of Australia.

Department of the Environment and Energy (DEE). 2016. About Commonwealth Environmental Water. https://www.environment.gov.au/water/cewo/aboutcommonwealth-environmental-water. Accessed 10 October 2017.

p.

FAO (2016a) Global diagnosis on groundwater Governance. Rome: FAO. 194

FAO (2016b) Shared global vision for Groundwater Governance 2030 and A call-for-action Revised edition, FAO 12p.

Faysse, N., Errahj, M., Imache, A., Kemmoun, H., \& Labbaci, T. (2014). Paving the way for social learning when governance is weak: Supporting dialogue between stakeholders to face a groundwater crisis in Morocco. Society \& Natural Resources, 27(3), 249-264.

Fienen, M. N., \& Arshad, M. (2016). The International Scale of the Groundwater Issue. Jakeman et al. (eds). In Integrated Groundwater Management (pp. 21-48). Springer, Cham.

Gardner, A. Bartlett, R. Gray, J. and Nelson R. (2017) Water Resources Law. LexisNexis.

Giordano, M. (2009). Global groundwater? Issues and solutions. Annual review of Environment and Resources, 34, 153-178.

Hardin, G. (1968). The tragedy of the commons. science, 162(3859), 1243-1248.

Holley, C. and Kennedy, A. (2019). Governing the Energy-Water-Food Nexus: Regulating Unconventional Gas Development in Queensland, Australia. Jurimetics. 59 (forthcoming, 2019).

Holley, C. and Sinclair, D. (eds) (2018) Reforming Water Law and Governance. From Stagnation to Innovaiton in Australia. Springer.

Jakeman, A., Barreteau, O., Hunt, R. J., Rinaudo, J. D., \& Ross, A. (2016). Integrated Groundwater Management: concepts, approaches and challenges. Springer. 
Marshall, V. 2017. Overturning Aqua Nullius: Securing Aboriginal Water Rights. Canberra: Aboriginal Studies Press.

McKay, C. and A. Gardner. 2013. Water accounting information and confidentiality in Australia. Federal Law Review 41:127-220.

Molle, F., \& Closas, A. (2017). Groundwater governance: a synthesis. Project Report - IWMI 6. International Water Management Institute, Colombo. 187 p.

National Competition Council (NCC) (2005)., Assessment of Governments' Progress in Implementing the National Competition Policy and Related Reforms. Melbourne: Commonwealth of Australia

National Water Commission (NWC). 2014. Water for mining and unconventional gas under the National Water Initiative. Canberra: Australian Government. Press.

Ostrom, E. 1990. Governing the commons. Cambridge: Cambridge University

Productivity Commission (PC) (2018) National Water Reform, Inquiry Report. Canberra: PC.

Tan, P.L., KH Bowmer and C Baldwin. 2012. Continued challenges in the policy and legal framework for collaborative water planning. Journal of Hydrology 474(12):84-91.

Van der Gun, J. (2012) Groundwater and global change: trends, opportunities and challenges. UNWWAP.

Villholth K.G, Lopez-Gunn E., Conti K., Garrido A., Van Der Gun J. (2017). Advances in groundwater governance. CRC Press.

WWAP (United Nations World Water Assessment Programme). 2015. The United Nations world water development report 2015: Water for a sustainable world. Paris: UNESCO 